\title{
Commercial and Political Regulation of Logistics
}

\author{
Vladimir Vasilyevich Scherbakov
}

Department of Logistics and Commercial Policy, St. Petersburg State University of Economics, St. Petersburg, Russian Federation Saint-Petersburg State University of Economics, Saint-Petersburg, Russian Federation; Correspondence: Vladimir Vasilyevich Scherbakov, 191023, Russian Federation, Saint-Petersburg, 21 Sadovaya Str

Doi:10.5901/mjss.2015.v6n5s4p555

\section{Abstract}

Knowledge of the causal relationships between management policy and the economy finds its practical importance in justifying the measures trade and political control of logistics. Targeting research is due to the need of creating analytical apparatus preparation of science-based trade-policy decisions. It monitors their implementation in connection with the formulation of the economic problems of the system and situational nature. The article describes the mechanism of trade and political control of logistics, structured by levels of economic hierarchy (macro-, meso-, and micro level) and management functions (planning, motivation, organization, control, and analysis/evaluation). The paper defines methods of trade and political control of logistic processes when making inter-economic exchange in the form of export-import supplies, cooperation, and organization of business entities. The paper investigates options for the preparation of decisions in the framework of integration of administrative and contractual arrangements that determine the development of modern forms of macro-, meso-, and micrologistics The paper substantiates the regulatory role of the interstate, regional organizations, sectorial and cross-sectorial, cluster, corporate associations in the implementation of the principles and rules of logistics, the construction of supply chain. The paper develops a presentation matrix of the mechanism, designed for the design and monitoring of trade policy-making, taking into account factors logistic efficiency. Approbation is used to prove the relationship of globalization, regionalization, and corporatization of logistics. The paper justifies the ideas and issues that shape the direction of the further development of research.

Keywords: trade policy, logistics, regulation, self-regulation, interfarm exchange, level of trade and regulatory policy, regulatory functions, trade and political decision, logistics coordination for barter processes, logistics efficiency

\section{Introduction}

The problems of development of the Russian economy, especially in recent years, are aggravated by the influence of political factors. Political risks are on a par with economic risks. Moreover, sometimes they are the root cause of them; they radically change the situation, break the trend of stable development is not less than a systemic crisis. The influence of politics discover many of the economic processes and forces that influence depend on the scale and content of measures of political control, somehow affecting management of the economy. This makes the need for in-depth knowledge of the patterns and causal relationships.

The problem stated in the title of the article goes back to the study of parity policy of management and economics in society. The evolution of his ideas is provided by the creative participation of scientists-an expression of the interests of the contemporary social formations. As a result of such research takes research and applied development contexts, relevant to the extent of posing the problems of system and situational (Garedagi, 2011; Popov et al., 2001; Chernyak, 1975). The modern significance of these issues in the light of the raised topics is emphasized in the statement of the President of the Russian Federation V. V. Putin: "We cannot do without an effective trade policy that reduces the cost of the path from producer to consumer" ("Rossiyskaya Gazeta", 2008).

\section{Literature Review}

\subsection{Correlation of Politics and Economy}

In support of evolutionary ideas, the study of the problem shall indicate the historical involvement in the process of formation of the representatives of economic thought. It is known, for example, that Adam Smith with his theory of the "invisible hand of the market", in fact, determined the priority of the economy to politics. In his view, an individual, aspiring for own benefit, regardless of their will and consciousness, is working to achieve the benefits and benefits for society. 
Under these conditions, the main task of the state is a policy of non-interference in all economic and social processes taking place in society for some of their exception. Only with such a condition, market economy is capable to achieve quickly and inexpensively the necessary results for the society.

Unspokenly, the ideological antithesis of Adam Smith in this issue was Karl Marx, who presented the whole economy only because of the policy, "where everything revolves around the class struggle", and it made its way to the minds of later generations of revolutionary thinkers. However, within the overall continuity of the ideas of MarxismLeninism, a reverse point of view was already able to form that the economy was primary in relation to politics. The idea generated by V. I. Lenin, it dominated for many years the Soviet government in the social attitudes of the USSR. However, the famous statement: "politics is the most concentrated expression of economics" (Lenin, 1963) was doubted by V. I. Lenin himself by the reasoning that "politics cannot but have precedence over economics". (Ibid.) In search of truth, analysts reveal the following. The first position, interpreting economic relations as a policy-defining beginning, means that only an objective-based approach to the economy makes it possible to develop appropriate forms of political economy. The second argues that any economic problems must comply with the main task of opposing classes-the conquest and preservation of political power. However, no politics is not an exact copy of a particular economic environment that provides an opportunity for political actions that take into account objective economic reality is only partly true. The conclusion is as follows: in the short term, these actions can be successful, but in the long run, they are clearly doomed to failure. (Matveev \& Fedotov, 2012).

Deep audit of the opinions is suggested by the fundamental study of the Nobel Prize Winner in Economics for 2008 Paul Krugman, who argues that the policy is primary in relation to the economy: "...The institutions, rules and political conditions far more influence on the distribution of income, and objective market forces-much less than that we try to assure in basic economics course" (Krugman, 2009).

\subsection{Politics Factor in the Management of Economics}

A brief digression into the theory attempted in the paper shows that in many case studies considered the level of the national economy, and this fully corresponds to the representation of politics in the context of governance arrangements. However, against the background of the famous interpretations of the term of "politics" as the activities associated with the distribution and exercise of power within a state or between states in order to ensure public safety, our stated problem meets another, no less broad interpretation of politics as a purposeful activity for the distribution and use of limited resources with an emphasis on the fact that politics is always implemented through a subjective activity of people, and therefore initially may not be objective. The politics expresses the views, way of thinking of people involved in the collection and analysis of information, the justification of any decision and its subsequent implementation. This implies that politics always contains elements of irrationality. Fundamentally important for the understanding of the politics is to remark that "politics is not only a process of management itself, the policy-it is the interaction of various elites, on the definition of the problems to be addressed by the country" (Matveev \& Fedotov, 2012), and the accompanying commentaries of the authors quoted by us: "Unfortunately, representatives of cooperating elites do not come from an objective assessment of the current situation and the factors that determine it, and the subjective interests of the group, aimed at implementing its often not in the interest of the whole society goals". (Ibid.) Despite the fact that these quotations well as theoretical digression as a whole, represent the highest level of political leadership, ideas contained therein about the role of the subjective beginning to provide a policy priority for the economy is quite relevant for the lower levels of the economic hierarchy, albeit with some differences. Thus, the level of government, perhaps more than at other levels, visibly manifests the dependence of the economy from politics in the change of political leadership, with the advent of the new political elite that detects and resolves the problems of a systemic nature. In other periods, the change of political course is determined by the need to solve situational problems.

Our position is based on the fact that revealed signs of mutual causal influence management policies and the economy require a compromise, that is, establishing parity in which the balance of political and economic forces varies depending on the ratio of system and situational factors: systemic factors work in favour of prioritizing the economy, situational factors - on the contrary, in favour of the priority management policies.

Scope of the politics addressing the economy is demarcated taking into account the structure of reproduction: the sphere of production; sphere of circulation of commodities, including the distribution and exchange; sphere of consumption; the scope of monetary circulation. In accordance with this principle, there are highlights in detail for the types of content-management policy, the economy and their typological characteristics are established, including the conjunction of economic policies with social. 


\subsection{Trade Policy as a Control Tool}

In view of this methodological approach, the trade policy can be defined as a tool for managing commodity circulation (in freedom of distribution-commodity exchange) in order to achieve development goals, disaggregated by level of administration. The restriction of this determination to the borders of the competence of individual control functions of the trade policy can be represented as a control tool. The basis of this action is a very specific point of view on the ratio of the control and regulation, the essence of which is as follows.

Management of economic systems is defined as activities aimed at achieving the objectives of the system and is organized as a process based on the use of appropriate tools and methods. If the system organization is applied, management activity involves the presence of an object (controlling subsystem) and the subject (control subsystem), the relationship between which is provided through the control action, a useful insight into management decisions. Management is carried out through the implementation of general and specific management functions.

Economy has three main types of management: project; regulation of the behaviour of the managed object; selfregulation (Figure 1) (Lopatnikov, 2003).

Depending on the content of the methods, management can be carried out on the administrative or economic basis. Administration suggests that the desired behaviour of the controlled subsystem and its elements (economic units) is achieved directives, control actions by prohibiting any action. At that, own interests of people that make up this economic unit, are not taken into account, though, of course, that each control action should serve their interests, and the interests of society as a whole. Economic management comes from the fact that in order to achieve the desired behaviour of the system, there should be created conditions, interesting for the economic chains in that very behaviour by setting prices, tariffs, regulations, etc. As a result, it turns out that the administration is correlated with longer controlled, economic-with regulation and self-regulation, even though the interface is not exactly fixed. It happens that the control action initiated by project solutions, is continued in the adoption of measures of a regulatory nature, which is the decision to repeat the common set of management functions: "planning—motivation—organization—control—evaluation/analysis"; functions are entered in the cycle until achieving control in its original formulation, or with some adjustments.

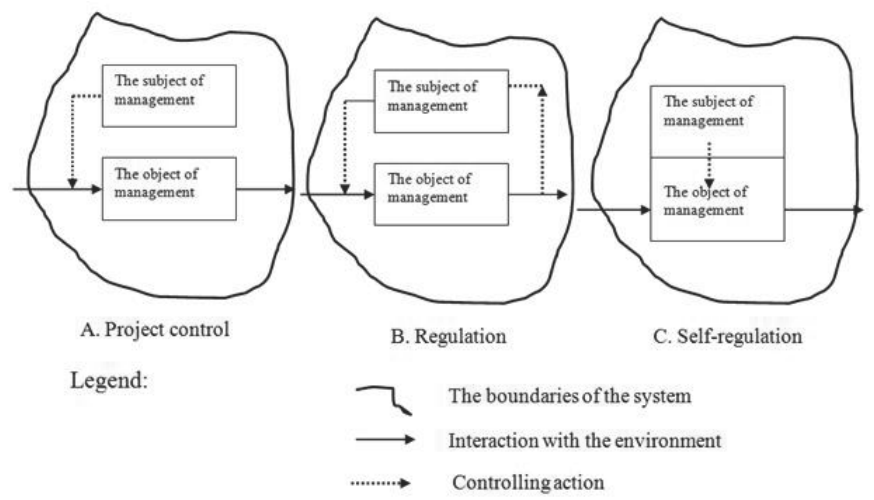

Figure 1. Control of the system

In this context, regulation is considered as a kind of control, as the process by which the characteristics of the controlled subsystem are retained on a trajectory predetermined by the control subsystem. Regulation, initiated implementation of control and analytic functions, is carried out on the deviations or endpoints. In the first case, the behaviour of the system undergoes a change when using the feedback found its deviation from the plan's tasks, rules, etc. In the second-when it reaches the level of a parameter, recognized as critical and inadmissible (Lopatnikov, 2003).

The regulatory process is produced in various ways depending on the nature of the system and its interactions with the environment. The regulation can be made by direct exposure of control subsystem onto the controlled one by removing of the external factor, under the influence of which the system exits the desired state through the insulation system from possible disturbances, and others.

Specific methods, as well as the purpose control methods are recorded in the content of the policy. 


\subsection{Trade Policy and Logistics}

In our case, we are talking about the trade policy, which is to be considered as a tool to control logistics. In this regard, it should be noted that logistics becomes an object of control in the economy to the extent that they relate to reproductive processes. Logistics is working to ensure product distribution, in terms of material and attendant financial, information, and service flow. The complexity of understanding of this issue is compounded by the fact that logistics itself is usually regarded as the science of management (Note 1). However, this aspect of the logistics can be considered and demand for interfacing trade policies and logistics as an interface as homogeneous transition to the policy environment for the transfer of control in the address of the logistics processes of technological character. Alternatively, it is possible stand on the position of the division of logistics and logistics management on the principle of the separation of the object and the manipulated object, allowing for the existence of a management entity-the body and the staff, enriched knowledge of science, and laying on him a special feature logistics management (organized in a systematic way, logistics management involves the creation of logistics systems). This argument can be developed if referred to the intensification of development of logistic management practices in companies, which, in fact, is the logistics management (Gusev \& Guskov, 2014; Kovalkov, 2009; Lukinskiyet al., 2011; Merzlyak \& Koskur-oglu, 2012; Pershin, 2014). Although, strictly speaking logistics, in our opinion, it can be considered any general economic and functional management, provided that it is carried out from a position of respect for the principles and rules of logistics. In this context, the principles and rules of logistics here seems to us appropriate to be reproduced, emphasizing that applied at the level of the enterprise (company), i.e. the main component of the economy, they discover their usefulness for the entire multi-level economic hierarchy (Protsenko \& Protsenko, 2012).

\subsection{Invariance of the Principles and Rules of Logistics}

Modern logistics is based on the principles of systematic, comprehensiveness, scientific rigour, specificity, constructiveness, reliability, variance, integrity, efficiency, flexibility, and preventiveness (Table 1). The principles mean the unity and serve the implementation of the rules of logistics, known as the "7R rule": "right product", "right quantity", "right condition", "right place", "right time", "right customer", "right cost", which mean the following: ensuring the right product in the right quantity and right quality specified in the right place at the right time for the right user with minimal costs (Logistics and Supply Chain Management, 2015).

Table 1. The principles of logistics

\begin{tabular}{|c|c|}
\hline Principle & The semantic content \\
\hline Consistency & $\begin{array}{l}\text { - Formation flow, selection of flow-forming objects into a separate controlled subsystem and application in } \\
\text { relation to it a systematic approach; } \\
\text { - Connection of costs for individual operations on the supply and transport of goods to the strategic plan of the } \\
\text { company; } \\
\text { - Achieving coherence with marketing logistics and production; } \\
\text { - Organization of supply, production, marketing, storage, and transportation as a pass-through material flow. }\end{array}$ \\
\hline Comprehensiveness & $\begin{array}{l}\text { - The formation of all types of provision (infrastructure) for traffic flows in specific circumstances; } \\
\text { - Coordination of direct and indirect participants in the movement of resources and products; } \\
\text { - Implementation of centralized control in meeting the challenges facing the logistics structure of the company; } \\
\text { - Strive of companies for close cooperation with external partners in the value chain and establishing strong } \\
\text { links between the various entities within the internal activities. }\end{array}$ \\
\hline Scientific rigour & $\begin{array}{l}\text { - Strengthening the settlement at the start of all stages of flow control-from planning to analyses, the } \\
\text { calculation of all the parameters of the flow path; } \\
\text { - Recognition of the status of qualified personnel important resource logistics company structures. }\end{array}$ \\
\hline Specificity & $\begin{array}{l}\text { - Clear definition of the specific objectives as a result of movement of the flow according to the technical, } \\
\text { economic and other requirements; } \\
\text { - Implementation of traffic at the lowest cost of all types of resources. }\end{array}$ \\
\hline Constructiveness & $\begin{array}{l}\text { - Flow scheduling, continuous monitoring of movement and change of each stream object, prompt adjustment } \\
\text { of its movements; } \\
\text { - Thorough identification details of all operations of logistics, storage, and transport of goods. }\end{array}$ \\
\hline
\end{tabular}




\begin{tabular}{|c|c|}
\hline Reliability & $\begin{array}{l}\text { - Ensuring reliability and safety, communications redundancy and means for change for, if necessary, the flow } \\
\text { path; } \\
\text { - Widespread use of modern means of movement and motion control; } \\
\text { - Increasing the speed and quality of information flow and improve its handling technology. }\end{array}$ \\
\hline Variance & $\begin{array}{l}\text { - Possibility to respond adequately to the company to fluctuations in demand; } \\
\text { - Purposeful creation of reserve capacity. }\end{array}$ \\
\hline Integrity & $\begin{array}{l}\text { - A desired quality inherent logistical system in general, but are not peculiar to any of its components } \\
\text { individually. }\end{array}$ \\
\hline Efficiency & $\begin{array}{l}\text { - The ability of the logistics system for a given level of development of market relations, production } \\
\text { technologies, with the data subjects of the system to achieve essentially the lowest possible logistics costs. }\end{array}$ \\
\hline Flexibility & $\begin{array}{l}\text { - Integration into the logistics system of mechanisms to predict trends in the external economic environment } \\
\text { and to develop appropriate actions. }\end{array}$ \\
\hline Preventiveness & $\begin{array}{l}\text { - Logistics permits only preventive control concept, warning of deviations, distortions and negative effects on } \\
\text { the logistics system. }\end{array}$ \\
\hline
\end{tabular}

With proper scientific approach to the management of the principles and rules of logistics, powered and embodied in the reproduction process, as evidenced by special studies (Brykin \& Shumaev, 2007), are able to provide the objective basis of the economy, which, in turn, can serve as a "concentrated expression" trade policy-this is the beginning of an objective, which is to influence the formation of the political decisions of the general content and targeted specifically aimed at regulating logistics.

\section{Methodology}

\subsection{Level Hierarchy of Trade and Political Control of Logistics}

The trade policy is an integral part of social and economic policy, and solves the problems of inter-economic exchange. Its dominant economic form is buying and selling as the main form of commodity-monetary exchange in a market economy. This form corresponds to the essential characteristics of the trade (transfer of goods from the seller to the buyer with the transfer of ownership), determining its economic, organizational, and legal differences from other forms of exchange, what are the lease (leasing), joint activities with a number of variants caused by border transfer of ownership to exchange products.

With this general theoretical formulation of the problem, in practical terms trade policy can be seen in the macro-, meso-, and micro-scale. In this hierarchy, the macroeconomic level correlates with the state of trade and political control of logistics, and meso and micro levels - with an average of self-regulation and the basic level of the economy.

The general idea, put forward by us in the form of a scientific hypothesis invariant levels, is as follows: when designing trade and political solutions to the problems of a systemic nature, the following is taken into account (including): the requirements of the principles and rules of logistics; when designing solutions situational effect of logistics as the beginning of the economic objective is levelled more active influence of other societal factors of decision-making among the economic, social, environmental and others, including purely political solutions.

\subsection{Macroeconomic Trade and Political Regulation}

\subsubsection{International Trade Policy and Global Logistics}

At the macroeconomic level, and in the global economy, the trade policy solves the problem of the international exchange. The main form of exchange is the international trade that is developing based on the international division of labour and expresses the mutual economic dependence between producers from different countries. International trade is carried out in the form of export-import supplies of goods, the ratio of which forms the trade balance.

In the organizational, economic, and legal regard, international trade is regulated by bilateral agreements and treaties communities that establish the principles of trade policy. Thus, the policy framework of the European Communities (initially_European Coal and Steel Community-ECSC, European Economic Community-EEC, European Atomic Energy Community-Euratom) consists of the five principles: free trade exchange (free trade); free movement of citizens of member countries; freedom of residence; freedom to provide services; free circulation of capital and free payment transactions (transfers of capital). One of the key decisions in the implementation of these principles was the creation of a common market, provides for the implementation of trade without mutual fees, merchandising contingent, 
and other restrictions on the appointment of a duty in relation to third countries (customs union), the introduction of the European Currency Unit-ECU, that globalization opened up opportunities for logistics. Further development of the integration process resulted in the creation of the European Union based on the signing of the Single European Act-the Maastricht Treaty (1987), going from the general to the single internal market. These and other similar solutions, in fact, are delimited by the rules of foreign and domestic policy of integration structures in the structure of the world economy, with efficient logistics, cost-sharing principle dictates, which is recognized as one of the essential arguments in justification of expediency of trade and economic integration in the conditions of increased specialization and production development cooperation.

The highest level of regulation of the principles of trade policy relates to the work of the World Trade Organization (WTO). WTO as an international organization promotes the ideas of free trade, liberalization of international trade and regulation of trade and political relations between the Member States of the organization. At that, the immediate task of the WTO is to establish and support the general principles of international trade, including: equal rights (common to all members of the organization the most-favoured nation); reciprocity (weakening bilateral trade restrictions); transparency (openness of the participants used trade rules); creating obligations on trade tariffs regulated by WTO bodies; safety valves (permissions for the introduction of separate trade restrictions to protect the environment, animal and plant health support).

The Russian Federation is included in the official list of participating countries of the WTO on August 22, 2012 with the serial number 156 and all its members should promote the harmonization of customs and trade rules, harmonization of procedures and cross-border product distribution logistics supply chain.

\subsubsection{National Trade Policy and Macro Logistics}

In the scale of the national economy, trade policy aims at creating favourable external and internal conditions for the development of the national economy. National trade policy is consistent with the monetary, fiscal and tax policy. Its tasks include:

- Protection of the national economy by trade and political means;

- Ensuring favourable conditions for the export of goods and services to the world market;

- Creation of favourable conditions for entering the world market of national suppliers of goods and services;

- Development of relations with foreign partners.

In order to integrate the Russian economy into the world economy, the Russian Federation in accordance with the generally recognized principles and norms of international law is involved in international agreements on Customs Union (Customs Union of Russia-Belarus-Kazakhstan) and free economic zones (Free Trade Area of the CIS, the Tumangan area).

However, the example of Russia can show a specific problem arising from the sale of membership in various kinds of alliances, agreements, on the one hand, and WTO membership, on the other, and methods for its solution. Currently, the status of regional associations has significantly increased, in particular the question of regional associations to find "their voice" at the World Trade Organization, with the prospect that the organization of the Union, individual countries will be able to transform itself into an alliance of regional organizations, the alliance of preferential regional agreements. It is believed that such a decision will pave the way for the development of new trading systems, as two or three dozens of regional players in the global market will be much easier to negotiate than all of its direct competitors.

We can assume that the implementation of these and other similar transformations will lead to some progress in the use of tools of political control means Macro logistics, and while the main measures of the trade policy in Russia are based on the use of mechanisms of customs and tariff regulations (export and import tariffs) and non-tariff regulation, what are the quotas and licensing of foreign trade. Exports and imports are carried out without any quantitative restrictions except for the purposes of national security, the fulfilment of international obligations, taking into account the state of the domestic market; and protection of the domestic market.

\subsubsection{Regional Trade Policy and the Diversification of Logistics}

From the set of trade-policy measures, it is clear that the trade policy of the state appears most often in the context of foreign trade. Meanwhile, at the macroeconomic level and at the national level, it is part of the internal socio-economic policy in the relevant sector of the economy-wholesale and retail trade. In Russia, with its exclusive territorial scale, trade policy is also becoming part of the regional economic policy. In this region, it is regarded as a quasi-state or quasi- 
corporation (Granberg, 2001), but the content of trade policy reflects its basic characteristics. For example, trade policy of the border regions mediates interstate exchange, providing infrastructure customs export, import and transit flows of goods; other territories trade policy controls are usually interregional exchange.

However, it is appropriate to recall the existence of different interpretations of the region, namely as a kind of geographic area of the planet, distributed between states-a region-quasi-market (Granberg, 2001). In the presence of co-ordination of exchange, the trade policy in the region can be correlated with the macro-economic level and shows the local control of the world economy. An example could serve the Eurasian Economic Community-EEC-regional association of a number of republics of the CIS area (Belarus, Kazakhstan, Kyrgyzstan, Russia, and Tajikistan)—an international economic organization created to promote its stakeholders formation of the Customs Union and the Common Economic Space, the implementation of other tasks, associated with the deepening of integration in economic and humanitarian areas, including tasks associated with logistics:

- Finalization of the free trade regime, the formation of a common customs tariff and a unified system of nontariff regulation;

- Establishment of common rules for trade in goods and services and their access to domestic markets;

- Establishment of a common unified system of customs regulation;

- Formation of a common market for transport services and integrated transport system;

- Development and implementation of interstate target programs and other.

The scale of logistics plans and prospects for the diversification of logistics interlayer illustrates the initiation of the project of connecting through the North-West Federal District of so-called Northern Corridor (Stockholm-TurkuHelsinki-St. Petersburg) and the Trans-Eurasian belt of a single infrastructure system, which should contribute to the formation of the Common Eurasian Economic Space. St. Petersburg State University of Economics (Maksimtsev, 2014) also outlines its participation in this project, including the ensuring of logistics.

An example of the Eurasian Economic Community and the fact that its real progress towards the creation of the Eurasian Economic Union-EAEU (initially, as of January 01, 2015 based on the Customs Union of Russia, Kazakhstan and Belarus, followed by the addition of Armenia) proves that the trade exchange of the region can serve economic community, but not each community membership is determined by its members to the same region. Levelling action factor of territorial proximity in the formation of quasi-market is demonstrated by the association of BRICS-a group of five emerging countries: Brazil, Russia, India, China, and South Africa, related by the economic agreements. It is known, for example, that the BRICS countries have concluded bilateral trade agreements, setting prices for many goods of mutual trade within the boundaries of mixed currency baskets, allowing the region to ease dependence on the BRICS currencies and the fluctuations of the world at the same time enhances the role of the national currency component in bilateral and multilateral projects of this group.

\subsection{Meso-Economic Trade and Political Self-Regulation}

\subsubsection{Voluntary Associations and Harmonization of Rules of Business Logistics}

The middle level of the national economy is represented by the integrated economic structures created in the form of voluntary associations. The contractors of the commodity market are the participants long-term economic relations in the construction supply chain need to find a coordinated management of enterprise logistics. Various forms of organization of joint activity contribute to its implementation. These are: administrative systems, partnerships and alliances, contractual systems, joint ventures, among which the organization of interdependent relations of participants increases with movement from the first to the last (Bowersox \& Closs, 2001). At the same time, they detect changes in business relationships of the partners with focus on:

- Cooperation and common interests of the supplier and the buyer;

- Long-term business relationships, when a supplier starts to participate in the discussion of the problem of meeting the needs of the buyer at the earliest stage;

- Guaranteed quality, based on the TQM model;

- Reducing the number of suppliers.

The Civil Code of the Russian Federation (the Civil Code) in its present wording (the Civil Code of the Russian Federation, 2014) prescribes the establishment of voluntary associations in the form of associations and unions, which are non-profit organizations. According to paragraph 1 of Article 121 of the Civil Code, the right to have contractual associations belongs to commercial organizations, pursuing the goal of coordinating their activities, as well as represent 
and protect common, including professional interests, to achieve community service and other, are not contrary to the law and with the nature of the non-profit purposes.

Of fundamental importance, thus, is the question of the preservation of the independence of members of the borders of voluntary association. In the design of commercial and political decisions, it must find its expression in the development of the relations of the transfer of commodity-money exchange is opposed relation to the free market exchange (in terms of supply quotas, the use of transfer pricing, netting, etc.). Trading policy mediated by such solutions solves problems with the creation of an organized market, a voluntary association of localized participants on mesoeconomic level across the integrated economic structures. The growing interest in this form of meso-economic organisation is identified by special events, such as the round table "The role of associations and unions in the development of the logistics sector of the Russian economy", initiated by the Committee on Logistics Chamber of Commerce of the Russian Federation and Ural Logistics Association on October 15, 2013.

Certain expectations in terms of strengthening the practice of trade and political control of logistics associated with the development of Russia's Institute of self-regulation in accordance with the provisions of the Federal Law No. 315-FZ as of 01.12 .2007 (as amended as of June 25, 2012), "On self-regulatory organizations". The basis for this is the general idea of the self-regulatory organizations such as non-profit organizations uniting business entities of certain sectors of production of goods (works, services) or uniting the subjects of professional activity of a certain kind. The first provides an opportunity to consider in detail the subject of self-content area of business logistics, referring to the formation and promotion among the participants of voluntary associations code of conduct as a sort of code of logistics. The second allows creating professional associations of logistics-logistics operators, for whom the formation of the professional code of logistics becomes even more urgent.

On this basis, we propose to the development the idea of extending the principles of the self-regulatory organization for the voluntary association of business structures that can be created based on the supply chains. It is supposed to rely on those organizational forms that allow correction of business principles participants-partnerships, associations, contract system, joint ventures, as well as use of the potential of new forms, in particular, the alliance form, given that individual study and practical use cases already exist in domestic science and practices (Blyakhman \& Petrov, 2003; Zagorskiy, 2004; Meshalkin et al., 2003; .Uvarov \& Shcherbakov, 1996).

An alliance is created as a union of several independent companies, which intend to engage in a certain kind of entrepreneurial activity, using the knowledge, materials, and other resources to each other, or to create conditions for the merger or acquisition of enterprises.

The justification for alliances to be exploring three distinct but interrelated aspects: subject (network), target (strategic), and organizational (management) aspects. The contents of the subject aspect make economic ties that reflect the composition of the material flow, the transfer of property rights between the partners, the movement of financial and information flows, serving and put all kinds of streams in a single, integrated flow. The features of economic relations define the boundaries of the property rights transferred-the possession, use, and disposal of commodities and tangible and intangible assets within and outside the alliance.

Identification of the interested companies-potential participants of the alliance is associated with study of its target aspect. The content of the latter determines the formation of common (harmonized) strategies of the alliance behaviour, which distinguishes it in particular from the contract systems. At that, the search for ways to harmonize the interests gives particular importance to the analysis of strategic alternatives in terms of their usefulness to all alliance members. Justification of strategic alternatives of economic behaviour of alliances assumes implementation of the principles of consistency, integrity, and optimization of total logistics costs.

The implementation of a common (harmonized) strategy of the alliance is initially to decide in regard to its organization. The content of the relevant aspects of the formation of alliances is defined by the contractual regulation of the relationship: the partners may enter into a system of agreements on mutual supply of goods or provision of services, which, in fact, sets rigid adherence of the counterparties to the economic ties.

The reality of the prospects for a common trade policy in the meso-economic structures of this type is caused by the action of the partnership agreement to develop a common strategic line of conduct in relations with partners in the organization of inter-firm commodity exchange. At that, this target orientation of logistics management strategy shall prioritize trade-policy choices.

\subsubsection{Cluster Associations and Logistical Support of Cooperative Ties}

Modern forms of organization of intra- and inter-sectorial co-operation are the integrated economic structures of the cluster type. Cluster associations, as opposed to the contractual ones, do not require the conclusion of special 
agreements between the parties. As part of the policy of cluster formation (with options: "top-bottom"—on the initiative of the Central Board, or "bottom-top"-on the initiative of local authorities or associations of local entrepreneurs) are determined by the interests of the participation of self-organization and self-development, which are supported by management, through regulation and self-regulation, while preserving the independence of economic entities. The complexity of the system is determined by the composition of building components, including manufacturing, software, maintenance, use, research, exports/imports (relative to the cluster structure), learning, which forms the background to the development of the network of economic relations.

The extent of clustering relates to the development of economic space. Cluster associations are created in two ways: spaceless (functional), the economic space of which is not clearly defined, and territorial, localized geographically.

In the variety of cluster associations created and produced in the Russian economy (sectorial and cross-sectorial, including discrete and process, innovative and creative, tourism, etc.), the selected position is occupied by transportation and logistics clusters (TLC), built on the active involvement of logistics operators. At that, logistics is being developed and invariantly becomes an object of trade and political control. The effectiveness of its instruments is detected through logistical support cooperative relations, based on the formation of co-operative and other economic links of supply chains. The peculiarities are in that the "non-logistical" clusters have logistics principles and rules working on the implementation of value chains; in transport and logistics cluster, where logistics is the basis of specialization, business entities that make up the core of the cluster structure, act directly involved in these chains.

The context of the study provides the interest in the problems of transport and logistics cluster associations by the fact that more than any other which provide docking macroeconomic and meso level of trade and political control of logistics. The Russian economy directly or indirectly covers the following within the scope of regulatory impact:

- Regional TLC. Created based on the transport systems of medium and large cities as well as metropolitan areas, they serve freight and passenger sectors, which may be both general and specialized infrastructure.

- Territorial TLC in varying stages of development exist in every major city. At the minimum level of development, TLC serve the needs of freight transport and movement of the population only within the territory of the city-cluster-based public transport. At a high level, territorial TLC serve not only local needs but also long-distance, inter-regional and international transport;

- Boundary TLC. Formed based on transport nodes at the intersections of major international transport corridors with the state border, they have cargo specialisation. Historically, boundary TLC were created in abutment to the railway border crossing (for example-International Centre for cross-border cooperation in the area of crossing the state border Ozinki, the Saratov region-Taskala, the West Kazakhstan region, Kazakhstan). Currently, however, when the operation of rail transport is comparable in terms of yield and even road transport operations, boundary TLC are based more often on motorways.

- Boundary transport and logistics clusters in addition to the transport companies, warehouses further include customs terminals-customs control zone in areas close to the border crossing points across the state border of the country. These clusters provide services related to the design of transport of goods by customs authorities and commercial and political control of the logistics corresponds to the customs regulation of trade flows;

- Port facility TLC. They are formed based on seaports and are positioned as the boundary TLC, mainly in the freight sector. At the same time passenger ports can be periphery for TLC. River ports, as the consequence of reducing the role of inland waterways and river transport, now often are not the centre of TLC, but they can also make their periphery. The exception are ports located on the inland waterways, but available for ships. The form of port special economic zones is applied to TLC created in the Ulyanovsk Region ("UlyanovskVostochnyi"), the Khabarovsk Territory ("Sovetskaya Gavan"), and in the Murmansk region.

The program of development of transport system of St. Petersburg and the Leningrad region for the period until 2020 provides creation of a TLC based on the seaports of Ust-Luga and Primorsk. Furthermore, given the geographical potential and the potential of territorial transport infrastructure of St. Petersburg and the Leningrad region, it is quite logical, in our view, raise the question of creating a multimodal TLC in the territory as an exclusive form of transport and logistics cluster association whose value is difficult to overestimate in the light of the integration of the North-Western region in the international economic exchange. 


\subsection{Micro-Economic Trade and Political Self-regulation}

\subsubsection{Enterprise and Commercial Logistics}

Trade policy at the micro level in the broadest sense defines barter activity of an economic entity (company), aimed at the completion of production processes in the sphere of circulation, the movement of goods from point of production to areas of consumption and sale. It solves the problems of the production and sale of products includes commodity, price, sales and service components as well as promotion of goods on the market. Considering, however, that trade occurs through a bilateral act, which involves the purchase of goods for sale, trade policy must be presented not only the interests of the seller, and the buyer, and therefore, in terms of logistics trade policy should regulate not only the output, but also input commodity flows. And if at the macroeconomic level, this aspect relates to the conduct of import operations, at the micro level, it expands the boundaries of trade and political relations to the business as a whole, encompassing also the procurement and supply of production and trade and political regulation applies to purchasing (procuring) and sales logistics, together constituting commercial logistics.

With proper justification, trade policies at the micro level are to extract synergy of commerce and logistics (Shcherbakov, 2011).

The synergistic relationship of commerce and logistics is found on the "docking lines": trade management (commerce) $\leftrightarrow$ contract logistics (logistics); management of commercial activity (commerce) $\leftrightarrow$ supply chain management (logistics) and others.

Commerce determines the field of activity and at the same time sets the framework within which logistics receives development, but does not limit them. The scope of application of logistics in today's economy includes not only processes of procurement and sales constituting a commercial activity of the enterprise for the production of a product, and the reproduction cycle of the product concerned in the sequence of steps, including the production process, as well as beyond the scope of activity of a particular company-manufacturer development processes product consumption and disposal—that formed the preconditions for the development of logistics in its integrated form.

The systems approach requires that both commerce and logistics be regarded as a set of processes and their elements-operations that are in interaction. Commercial activities are carried out in a combination of processes and operations of commercial content, preparation and barter transactions. Logistics activities carried out in a combination of processes, and those, which are connected with a business, provide the execution of transactions-the organization of product distribution from the producer to the consumer and to ensure the provision of a counter. Management of commercial activities, as well as logistics, is carried out on a systematic basis.

A systematic approach to the organization of commerce and logistics is expressed in the creation of similar systems, and if the logistics system have now become quite common organizational solution, both at the level of individual enterprises, and the scale of the integrated economic structures of meso-level (sectorial, cross-sectorial, regional complexes) in macro-level scale of the national economy, largely due to the fact that took over the function of the system integrator in relation to local systems, sub-logistic systems.

According to the general rules, the management is based on a strategic basis. At the same time, systemic problems are solved through the development of the strategy adopted in the horizon of planning, situational problems-in terms of their current adjustment within the general procedure described by the contour of strategic management (Figure 2) (Strategic Management, 2005), which reveals their potential effects, including taken trade and political decisions.

The place of trade policy in the loop of strategic management is related to goal setting. Goal settings to address the systemic problems identified by carrying out strategic analysis, determine the content of the base, the overall economic development strategy; basic strategy is being structured for management levels to ensure the strategy (functional units' level) and operating strategy (linear units' level). The diversified companies of the corporate type have a more complicated block diagram of the strategic planning because of the presence of business (production and business, competitive) business strategies (Thompson \& Strickland, 1998). The place of logistic strategy in these schemes is defined at the level of providing. That is how management is formed in stable operating conditions. 


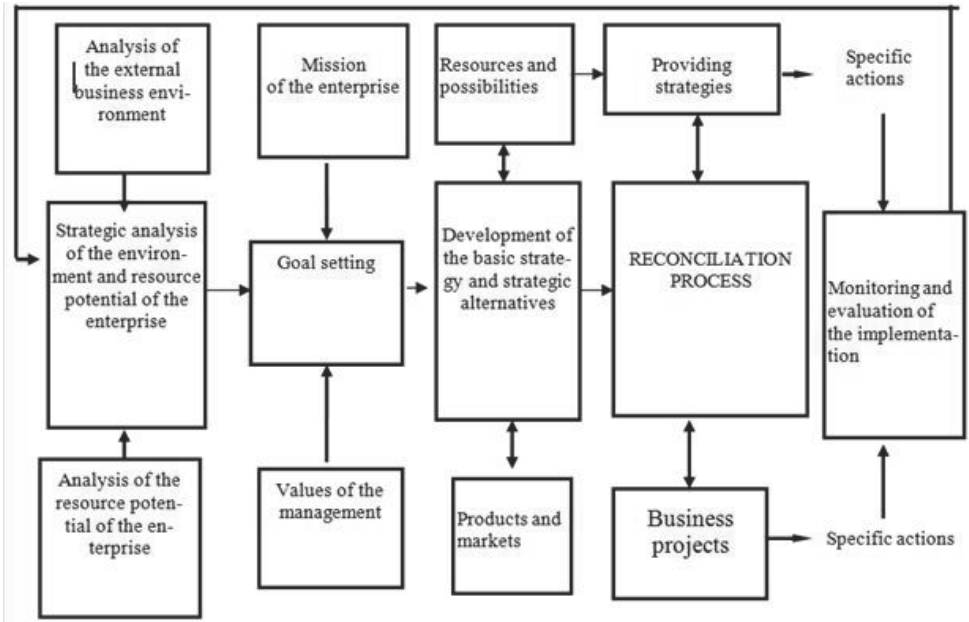

Figure 2. Circuit of the strategic management

In case of violation of stability, when the trade policy focuses on problem solving situational nature that have arisen on the horizon operational strategic planning, meaningful part of the circuit to be significantly changed. The entire scheme of describing the process of planning is transformed into a regulatory framework with the relevant structural and advances meaningful to it. Initially taking that the trade policy fits into the contour of strategic planning as an element of goal setting, acting targetly against providing logistics strategy (as well as marketing strategies) despite the fact that the basic strategy is a strategy of sales development, in terms of situational instability in the transformation, it is logical to imagine logistics strategy basic strategy. Alternatively, it is possible, in our view, present a basic strategy of marketing logistics (Christopher \& Peck, 2005), considering it the product of negotiation strategies, logistics and marketing.

\subsubsection{Corporation and Coordinated Management of Integrated Commercial Logistics}

Commercial logistics as an object of trade and political control across the enterprise becomes more complex shape to create corporate-type associations. Logistics in a corporation becomes a means of optimizing business processes and threads, capable of ensuring the coordinated use of the advantages of the integrated management of business logistics. Developing within the integrated economic structures-vertical, horizontal or mixed structures, corporate logistics provides processes of the exchange of goods and/or activity of differing nature of the relationship of the participants, depending on the degree of integration-a "soft", while preserving the economic independence of business organizations and corporations as part of " hard "-the loss of independence and the creation of a new legal entity.

Among the many signs of corporate business organization (Logistics and Supply Chain Management, 2015), a significant one in terms of logistics management, is the scale of corporations (local-geographically concentrated structure, regional, inter-regional and national-geographically distributed structure, respectively, within the region of the country, on the scale of two or more regions of the country, across the country, international-geographically distributed structures with its subsidiaries in different countries, whose operations are controlled from the headquarters in own country, multinationals-geographically distributed structures with subsidiaries in the world, which operate quite independently, transnational corporations-geographically distributed structures with mixed versions of the business organization, that act, for example, as international in one region, and multinational-in the other).

Creating local and regional corporations involves the transition from the microsystem to the organization of logistics to meso-logistical systems; accordingly, the development of inter-regional and national corporations accompanied by the creation macro-logistical systems, and international, multinational, and transnational corporations-mega-logistical systems. At the same time as the complexity of the structure of the structure raises the question of the development of the Code of Corporate Logistics (Shcherbakov, 2011), the status of which (especially if "hard" integration) can be raised to the corporate standard.

It is appropriate to draw attention to the fact that the regulated trade policies, logistics associations of corporate 
type, as the logistics cluster associations, work to erase the boundaries of level in the current economic hierarchy. Thus, it facilitates the transition from hierarchical to a network structure of the economy.

\section{Results}

Comprehensive understanding of the mechanism of the impact of trade policy on the regulation provides logistics solutions matrix (Table 2). Highlighted fields in the matrix are the areas of regulation, justification of the adoption and monitoring of trade policy-making to ensure the regulation of the logistics processes and in aggregate flows of goods movement. At that, the decision macroeconomic level are addressed to macro logistics and back to the global logistics to the best of controlled inclusion of logistics processes in global processes, as well as they fall to lower levels, affecting meso- and micro-logistical processes. A similar pattern can be assumed in respect of other levels of decision-making, i.e., the economic hierarchy as a whole.

Table 2. The study of measures for trade and political control of logistics

\begin{tabular}{lccccc}
\hline \multirow{2}{*}{ The levels of economic hierarchy } & \multicolumn{5}{c}{ Function for logistics control/self-control } \\
\cline { 2 - 6 } & Planning (P) & Motivation (M) & Organization (O) & Control (C) & Analysis/Assessment (A) \\
\hline Macroeconomic level (1) & $1 \mathrm{P}$ & $1 \mathrm{M}$ & 10 & $1 \mathrm{C}$ & $1 \mathrm{~A}$ \\
Mesoeconomic level (2) & $2 \mathrm{P}$ & $2 \mathrm{M}$ & $2 \mathrm{O}$ & $2 \mathrm{C}$ & $2 \mathrm{~A}$ \\
Microeconomic level (3) & $3 \mathrm{P}$ & $3 \mathrm{M}$ & 30 & $3 \mathrm{C}$ & $3 \mathrm{~A}$ \\
\hline
\end{tabular}

The versatility of our proposed form is that the matrix can fix solutions not directly pursuing logistic targets, but anyway affecting the logistics system state and/or conditional "lance" problem situation in the development of logistic processes. Depending on the magnitude, these decisions may cover a number of fields, the sequence of levels and a set of control functions. Thus, an all-encompassing, all-pervasive in this sense, decision can be considered the use by Russia of economic sanctions in response to the sanctions imposed by the United States and European Union countries due to the political developments in Ukraine. Its status and importance now are determined by the fact that the decision is the correction measure of trade policy decision-making at all levels of the hierarchy of the domestic economy.

By their nature, the solutions recorded in the matrix are design solutions in the broadest sense of the project as an appropriate measure (Project Management, 2001), which differ in the level of sales (actual project, program, system) and scale (small, medium, megaproject ) (Project Management, 2001).

The matrix form is fairly intuitive to interpret the idea and methods of implementation of trade policy decisions in terms of its impact on logistics. This can be judged on the basis of rapid testing, performed by us with the assistance of information from the open literature, specifically-the newspaper "Kommersant". Intentionally short term, selected to summarize the material-the current calendar decade at the time of testing (13-22 April 2015), suggests that the studied problem is the subject of constant attention of professional analysts and scientists, and we presented it in a structural way.

The following are our identified positions of the matrix (optional).

- " $10-1 C "-a$ counter-ban on the import and export of Russian and Kazakh goods ("Kommersant", 2015);

- "1P-1O-1A-2P-2O-2A"-the organization of deliveries of Russian military equipment abroad ("Kommersant", 2015);

- "3M-30-3A"-the creation of a unified transport and logistics company's business organizations resident in Russia, Belarus and Kazakhstan ("Kommersant", 2015);

- "3P-3M-3O-3C"-the localization of road-building and municipal equipment based on Tosnenskiy Mechanical Plant ("Kommersant", 2015);

- "10-1A-1M"-the construction of the gas pipeline "Turkish Stream" through the territory of Greece ("Kommersant", 2015);

- "3O-3M-3C-3A"-the initiative of the Association "Russian Automobile Dealers" on the introduction of restrictions on the sale of used cars by individuals ("Kommersant", 2015);

- "10-1M-1C-1A-30-3M-3C"-the exploration and production of hydrocarbons in the North Sea ("Kommersant", 2015);

- "1P-1O-1M-1C-1A-2P-2M-2O"-the assessment of the prospects of gas supplies by "Gazprom" in the EU through the "Turkish stream" ("Kommersant", 2015).

It shall be noted that the decisions of tiered scale reveal their complementary or contradictory. The generalization 
of this information, as well as the attempted research approach in general, bring to the formulation the problem of efficiency assessment for the logistics trade-policy decisions. The task can be accomplished in two ways: from the position of the target and cost-effectiveness assessments, but each time taking into account actions of political risk factor, transformed by the experience of the analysis of the current situation of economic sanctions in transactional risk.

\section{Discussion}

The foregoing provides a basis to understand that trade policy in the economy as a complex of measures on the organization of commodity exchange has several forms of implementation. Given that the term is most often used in the context of the organization of foreign trade activities of the state, it seems reasonable to distinguish its variants: international, national, regional, corporate trade policy, and trade policy of business.

Regardless of the version of the subject area of trade policy determines the solution of a number of key issues:

- What to sell (buy). Traded commodities include tangible and intangible assets, including services, intellectual property;

- Whom to sell (from whom to buy). The priorities of trade policy relate to the interests of (economic, social, etc.) of the exchange participants and are expressed in different kinds of preferences;

- How to sell (buy). This question is the most valuable for the elaboration, as it provides a record of such nuances as the equivalence of schemes and barter, counter form of logistics, including shipping of goods, service, recycling, and others.

The content of trade policy utilizes legal, economic, and organizational management practices that embody the principles and rules of logistics. At the same time, the ratio of the use of border policy (direct) and indicative (indirect) form of implementation of trade policy measures vary at different levels of economic hierarchy.

Regardless of the level of organization in the development of trade and political relations, the practice of trade missions becomes important. Representative offices are functioning successfully at the macroeconomic, microeconomic and mesoeconomic levels and generally as an institution at the stage of trade policy can act as the conductors for the principles of logistics, just as at the stage of its implementation contribute to the implementation of the principles of trade policy in the economy. Modern Russian trade missions abroad solve the tasks of promoting domestic companies in the promotion of world markets, establishing mutually beneficial cooperation with foreign partners in the changing geography of the network, the shift to the emerging markets of Asia, Latin America, Africa and CIS markets.

\section{Conclusion}

The obtained results and discussion provide a basis to formulate some ideas to be further investigated.

1) On the different levels of economic hierarchy, logistics shows signs of influence on trade policy, with a much wider than that which can be described by the communication line "trade logistics-trade policy". Trade policy as an element of social and economic policy is under the influence of logistics in the variety of its content options identified in the context of a large-scale, resource, functional, logistics industry classification applicable to the trade and economic sphere.

2) Influence of logistics on the formation of trade policy is mediated by its principles and rules, which, in turn, are derived from the laws of the organization. The logic is as follows: general economic laws of the organization (the laws of synergy, proportionality, ontogenesis, preservation, analysis, and synthesis of unity, awareness ordering of the composition (Radchenko, 1988) define the principles of organization of logistics (systematic, scientific, constructive, reliability, variation, integrative, efficiency, flexibility, proactive and others), and the principles of set regulations aimed at to implement rules that are embodied in the measures of trade policy and implemented in it. At that, the rules of logistics are amenable to "convolution" and summarize the requirements of the organization of goods movement in the exchange on terms of customer focus (supply of the necessary goods to the client declared their needs, in the right amount, the right quality, at the right time in the right place) and profitability (with the cost acceptable for the client). The rules thus define substantive aspects of the work with potentially manage complex structured flow integrated over commodity flows.

3) The nature of logistics in trade and political decisions are made by a causal relationship, the possibility of direct regulation that increases from a higher level of decision-making to a lower-from macroeconomics to the meso and micro-economics. In accordance with the decision-making levels, logistics through trade policy should work to ensure the competitiveness of the national economy (a macroeconomic level), the regional economy (meso level), and business entities (the microeconomic level). In view of the instruments, logistics 
shows the greatest effectiveness at the micro level. Integrated logistics helps to achieve a high utility content, form and place the completed production and lodged to the exchange of goods under the control of the price of consumption. This is the media to manifest system relationship of logistics and trade policy. Situational relationships are usually caused by the reaction of the trade policy of logistics. At that, the support of trade policy-making requires evaluating their logistics efficiency, as evidenced by significant changes in product distribution processes occurring under the action of anti-Russian economic sanctions.

4) A key measure of the logistic support of integration processes in the field of trade policy can and should be the development of mechanisms to regulate the organizational and economic interactions with the logistics of the transition from economic ties to the integrated logistics supply chains that meet modern trends of business. The development and adoption of decisions shall be related to innovative approaches, taking into account that in a globalized economy, the dual with the trends of regionalization and corporatization, the supply chain is increasingly complicated in their configuration, expanded to the maximum extent and take cross-border form. Under these conditions, the major target of trade policy priority shall be to ensure invariant logistical coordination barter processes.

Note 1. In the interpretation of the scientific school of the department of logistics and trade policy of St. Petersburg State University of Economics, "logistics is the science of materials management and related information, financial, service, and other streams in order to optimize the functioning of economic systems through the effective use of all resources" (Logistics and Supply Chain Management, 2015).

\section{References}

Blyakhman, L. S., \& Petrov, A. B. (2003). Integrated technological chain as an object of control in the global economy. Problems of modern economy, $1,45-49$.

Bowersox, D. J., \& Closs, D. J. (2001). Logistics: Integrated supply chain: Trans. from English. M.: Olimp-Business.

Brykin, A. V., \& Shymaiev, V. A. (2007). Formation of an industrial policy based on logistics. M.: MosgorTsNTI.

Chernyak, Yu. I. (1975). System analysis in managing economy. M.: Economy.

Christopher, M., \& Peck, H. (2005). Marketing Logistics. M.: Publishing house.

Civil Code of the Russian Federation. (2014). In G. Y. Kasyanova (Ed.), Commentary on the recent changes. M.: ABAK.

Garaedagi, J. (2011). Systems thinking: How to manage the chaos and complex processes. Platform for modeling business architecture (p. 480). Minsk: Grevtsov Books.

Granberg, A. G. (2001). Fundamentals of the regional economy: Textbook for high schools (p. 495). M.: SU HSE.

Gusev, A. M., \& Guskova, S. V. (2014). Logistical support of trading activities for LLC "LUKOIL-Severo-Zapadnefteprodukt". Paper presented at the integration of logistics capacity in the global economy: Proceedings of the international scientific-practical conference (pp. 19-22). St. Petersburg.: Publishing house of SPbGEU.

Kovalkov, V. A. (2009). The system of measuring the level of logistics services. Logistics and Supply Chain Management, 6, 3-39.

Krugman, P. (2009). Liberal's credo (p. 366). M.: Europe.

Lenin, V. I. (1963). Again on the Trade Unions, the Present Situation and the Mistakes of Comrades Trotskiy and Bukharin. Complete set of works (Vol. 42, pp. 264-304). M.: Politizdat.

Shcherbakov, V. V. (Ed.). (2015). Logistics and Supply Chains Management: The textbook for undergraduate academic students (p. $582)$.

Lopatnikov, L. I. (2003). In G. B. Kleiner (Ed.), Economics and Mathematics Dictionary: Dictionary of modern economics (p. 520).

Lukinskiy, V. S., Pletneva, N. G., \& Shulzhenko T. G. (2011). In V. S. Lukinskiy (Ed.), Theoretical and methodological problems of logistics processes in the supply chain (p. 242).

Maksimtsev, I. (2014). The university participates in the new industrialization. Expert North-West (p. 7).

Matveev, V. V., \& Fedotova, L. S. (2012). The problem of public choice (Vol. 4, pp. 52-60). Bulletin of the Udmurt University.

Merzlyak, A. V., \& Koskur-oglu, E. O. (2012). Information basis of logistical management (p. 210). SPb.: Publishing House "Petropolis".

Meshalkin, V. P., Dovi, V., \& Marsanic, A. (2003). The strategy of management for logistics chains of chemical products and sustainable development (p. 542). M.: Russian ChemicalTechnological University.

Pershin, I. V. (2014). Logistical rules for the organization of work with a consolidated fleet of vehicles. Paper presented at the integration of logistics capacity in the global economy: Proceedings of the international scientific-practical conference (pp. 26-30). SPb.: Publishing house of SPbGEU.

Popov, V. M., Lyapunov, S. I., Filippov, V. V., \& Medvedev, G. V. (2001). Situational analysis of business and decision-making practices. M.: KnoRus.

Protsenko, O. D., \& Protsenko, I. O. (2012). Logistics and Supply Chain Management-a look into the future: macroeconomic aspect (p. 192). M.: Publishing House "Delo" of RANHiGS.

Radchenko, Y. V. (1998). The laws of the organization and their role in the restructuring of the management of the economy. Bulletin of the Academy of Sciences of the USSR (pp. 3-21). Economic Series.

Shcherbakov, V. V. (2011). On synergy connection of the innovative solutions in commerce and logistics. Logistics innovation in 
commerce and marketing: Collection of reports (pp. 3-7). SPb.: Publishing house of SPbGUEF.

Shcherbakov, V. V. (2011). The logic of setting and solving the problem of the formation of the Corporate Code of logistics. In V. V. Shcherbakov, A. V. Parfyonov, \& E. A. Smirnova (Eds.), Commercial and Logistics: Coll. of scientific works (Vol. 9, pp. 3-9).

Petrov, A. N. (Ed.). (2005). Strategic management (p. 496). SPb.: Piter.

Thompson, A. A., \& Strickland, A. J. (1998). In L. G. Zaitsev, \& M. I. Sokolova (Eds.), The art of developing and implementing the strategy: Trans. from English (p. 576). M.: Banks and stock exchanges, UNITY.

Uvarov, S. A., \& Shcherbakov, V. V. (1996). Justification of logistics alliances in commerce (pp. 105-112). Bulletin of St. Petersburg University of Economics and Finance.

Zagorskiy, A. L. (2004). Competitiveness of integrated business groups (p. 342). SPb.: Publishing house of NSC "ROST". 